\title{
THE PLATYCERATACEAN GASTROPOD CYCLONEMA (CYCLONEMA) HIIUMAA TEICHERT, 1928 FROM THE LLANDOVERY (SILURIAN) OF ESTONIA
}

\author{
Mare ISAKAR
}

Tartu Ulikool (University of Tartu), Vanemuise 46, EE-2400 Tartu, Eesti (Estonia)

Presented by D. Kaljo

Received 23 January 1995, accepted 28 March 1995

Abstract. A platyceratacean gastropod species Cyclonema (Cyclonema) hiiumaa Teichert, 1928 is redescribed. The distribution and life habits of this species are discussed.

Key words: Gastropoda, Cyclonema, Silurian, Estonia.

One of the few records about Silurian gastropods from Estonia is that of Teichert (1928, pp. 69-70, P1. V, figs. 21-23). He has established a new species of the genus Cyclonema, describing shortly only one specimen from Hilliste (p. 69) and figuring another one from Pullapää (Pl. V, figs. $21-23)$. Both specimens seem to be lost.

As to the specimens used by Teichert, the attempts to find them have failed. Curt Teichert, being a student at Köningsberg University, presumably also preserved them there (in his paper he has not mentioned the place). An inquiry for these specimens at the Kaliningrad (previously Köningsberg) University (Krasnov, 1995, written comm.), Naturmuseum Senckenberg in Frankfurt am Main (Plodowski, 1994, written comm.), as well as at the Naturkundemuseum Berlin (Schultz, 1994, oral comm.) was without success.

All specimens, except fig. 6 , were coated with ammonium chloride before photographnig. Figs. 1-3. Cyclonema (Cyclonema) hiiumaa neotype, Llandovery, Hilliste Formation, Hilliste quarry, TUG $66 / 110, \times 4$. 1, lateral view showing slightly irregular growth lines; 2 , apertural view showing thickened and reflexed inner lip; 3 , basal view showing base and umbilical region.

Fig. 4. C. (C.) hiiumaa paratype, Llandovery, Hilliste Formation, Hilliste-2, TUG 66/107, view showing ornamentation, $\times 4$.

Fig. 5. C. (C.) hiiumaa paratype, Llandovery, Hilliste Formation, Hilliste quarry, TUG $66 / 117$, lateral view, $\times 4$.

Fig. 6. C. (C.) hiiumaa compressed paratype, Llandovery, Hilliste Formation, Hilliste quarry, TUG 625/5, apical view, $\times 10$. 

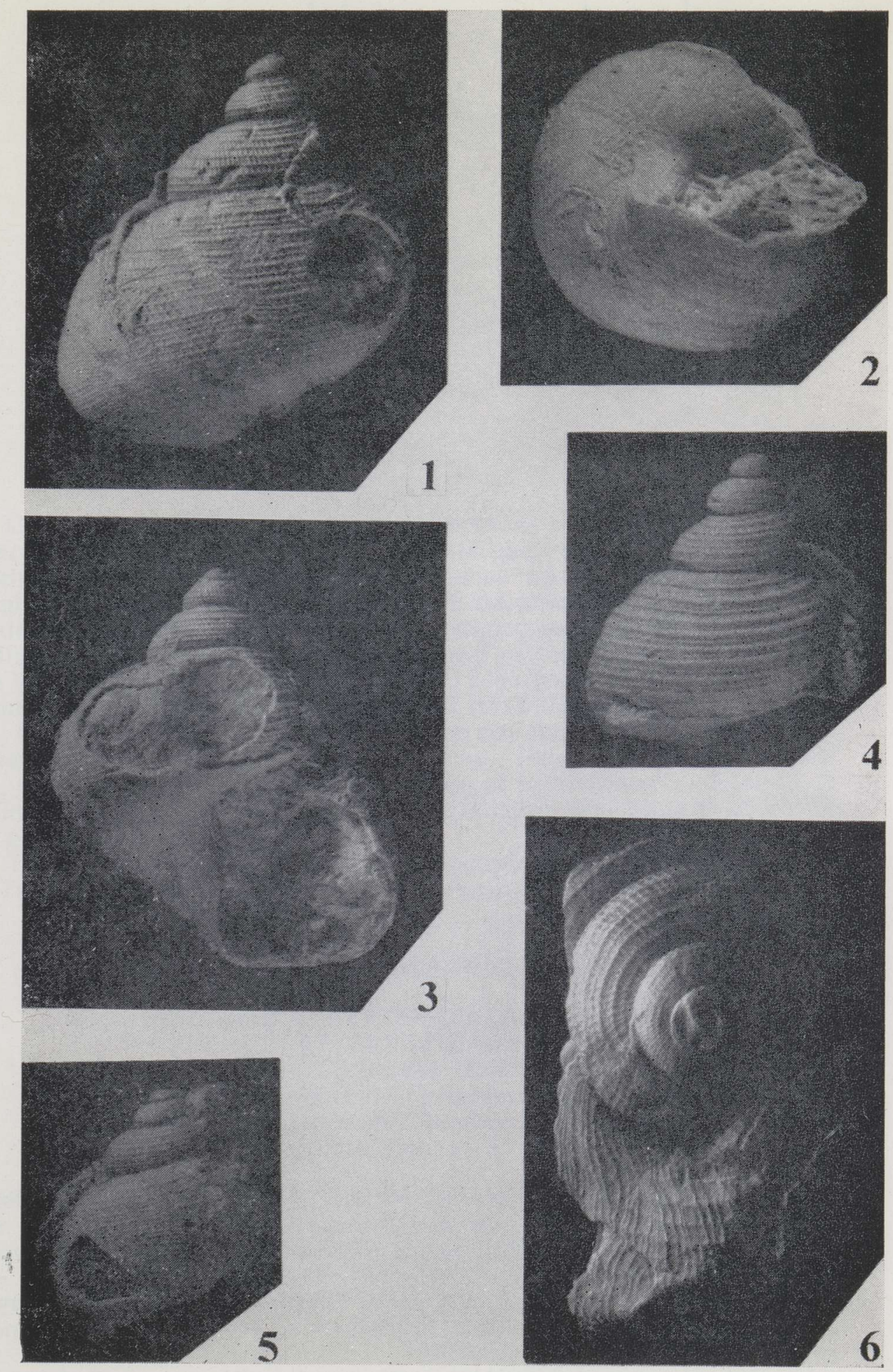



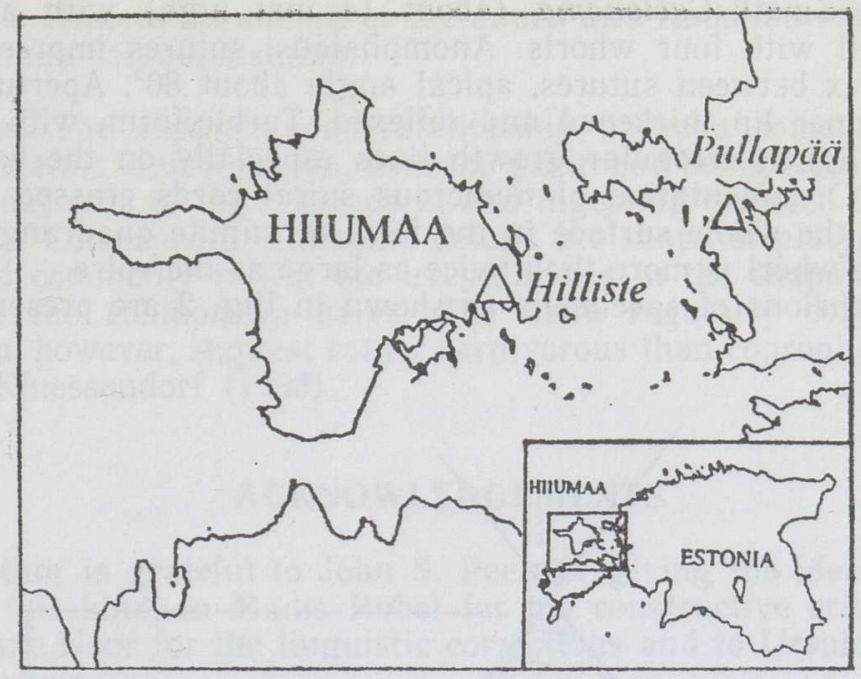

Fig. 1. Location of the Hilliste and Pullapää sections, Estonia.

Up to now a number of additional specimens of Cyclonema $(C$.) hiiumaa have been collected from the Hilliste quarry and from a temporal ditch nearby, named Hilliste-2, on Hiiumaa Island (Fig. 1). In both localities the boundstone of the shoal reef facies and surrounding coarsegrained skeletal grainstone crop out. Stratigraphically they belong to the Hilliste Formation which forms the topmost part of the Juuru Stage and the lowermost part of the Raikküla Stage, Llandovery (Nestor, 1993). The commonest gastropod of the Hilliste reef is small Platyceras (Platyostoma) sp., besides various other taxa of the same size including Cyclonema (C.) hiiumaa, Trochonema sp., Megalomphala sp., Phanerotrema sp., Liospira sp., Gyronema? sp. The present description of Cyclonema $(C$.) hiiumaa is mainly based on all material available, in number amounting to 16 shells of good preservation.

The material is deposited in the Geological Museum of the University of Tartu (TUG), Tartu, Estonia, under collection numbers TUG 66, 40, 625.

\section{SYSTEMATIC PALAEONTOLOGY}

Superfamily PLATYCERATACEA Hall, 1859

Family PLATYCERATIDAE Hall, 1859

Genus Cyclonema Hall, 1852

Subgenus Cyclonema (Cyclonema) Hall, 1852

Cyclonema (Cyclonema) hiiumaa Teichert, 1928 Plate, figs. $1-6$

Neotype. Selected here shell TUG 66/110 from the Hilliste Formation of the Juuru and Raikküla stages, Llandovery; Hilliste quarry, Hiiumaa Island, Estonia. Collected by Mare Isakar, 1986.

Figured specimens. Shells TUG 625/5, 66/117 from Hilliste; TUG 66/107 from Hilliste-2.

Material. Cyclonema (Cyclonema) hiiumaa; Hilliste quarry-13 shells, Hilliste-2 - three shells. 
Description. Small Cyclonema (about $14 \mathrm{~mm}$ high) with a relatively gradate shell with four whorls. Anomphalous, sutures impressed, whorl profile convex between sutures, apical angle about $80^{\circ}$. Aperture broadly D-shaped, inner lip thickened and reflexed. Turbiniform, with wavy surfaces and slightly irregular growth lines especially on the base (Plate, figs. 1, 5). Ornamentation of numerous spiral cords crossed by growth lines covers the whole surface in the form of minute quadrangles (Plate, fig. 4). Base whorl is more than twice as large as the spire.

The dimensions of specimens as shown in Fig. 2 are presented in the Table.

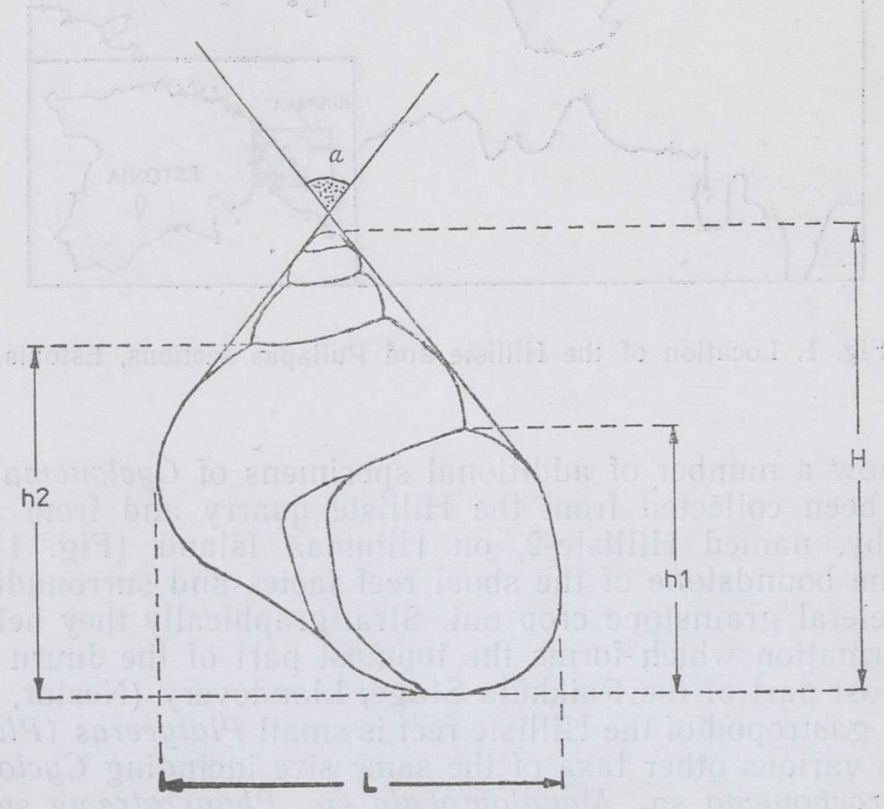

Fig. 2. Conispiral gastropod shell, showing locations of measurements (Table). $H$, height of the shell; $h 1$, height of the aperture; $h 2$, height of the last whorl; $L$, maximum diameter; $a$, apical angle.

Statistics of specimens. Measurements in $\mathrm{mm}$

\begin{tabular}{l|r|r|r|r|r|r}
\hline Number & $H$ & $h 1$ & $h 2$ & $L$ & $a$ & $H / L$ \\
\hline $66 / 110$ & 14 & 7 & 11 & 12.5 & 78 & 1.12 \\
$66 / 113$ & 8 & 4 & 7 & 8 & 82 & 1.00 \\
$66 / 114$ & 14 & 7 & 13 & 13 & 80 & 1.08 \\
$66 / 117$ & 9 & 4,5 & 8 & 8 & 78 & 1.13
\end{tabular}

Discussion. Cyclonema (Cyclonema) hiiumaa is distinguished from Cyclonema (C.) striatum Lindström (1884, p. 176, PI. XVII, fig. 48; Pl. XVIII, figs. 39-42) from the Slite Beds, Gotland Island, by its completely different shape of the aperture, more convex whorls and greater base whorls. More similar is Cyclonema (C.) canceliatum Lindström (1884, p. 175, Pl. XVIII, figs. 25-27) from the Hemse Beds, Gotland Island, which differs in an ovate aperture and thin lips with a gently curved notch in the outer one, never seen in the aperture of the described species. 
Occurrence. Hilliste Formation of the Juuru and Raikküla stages, Llandovery, Hiiumaa Island, Estonia.

Life habits. The coprophagous relationship between some platyceratids and echinoderms is well known, with the gastropod being closely associated with the anal area of the echinoderm and ingesting expelled faeces (Bowsher, 1955). Consequently, in some details the shape of platyceratid aperture would commonly reflect the irregularities in the shape of the upper surface of the echinoderm calyx. The more regularly coiled shells of Cyclonema, however, suggest rather carnivorous than coprophagous habits, noted by Kluessendorf (1983).

\title{
ACKNOWLEDGEMENTS
}

The author is grateful to John S. Peel for giving the idea to write an article of this kind, to Madis Rubel for his constructive criticism of the text, to Anne Noor for the linguistic corrections and to Ursula Moldov for the SEM photo.

\section{REFERENCES}

Bowsher, A. L. 1955. Origin and adaptation of platyceratid gastropods. Paleont. Contr. Univ. Kansas, Mollusca, Art. 5, 1-11.

Kluessendorf, J. 1983. Observations on the commensalism of Silurian platyceratid gastropods and stalked echinoderms. Wisconsin Acad. Sci. Arts, Letters, 71, 48-55. Lindström, G. 1884. On the Silurian Gastropoda and Pteropoda of Gotland. Handl. Svenska Vetenskap Akad., 19.

Nestor, H. 1993. Catalogue of Silurian Stratigraphic Units and Stratotypes in Estonia and Latvia. Tallinn.

Teichert, C. 1928. Stratigraphische und paläontologische Untersuchungen im unteren Gotlandium (Tamsal-Stufe) des westlichen Estlands und der Insel Dagö. Neues Jahrb. Mineral., Geol. und Paläontol., Beil.-Bd. LX, Abt. B.

\section{EESTI LLANDOVERY (SILUR) GASTROPOODI CYCLONEMA (CYCLONEMA) HIIUMAA TEICHERT, 1928 KIRJELDUS}

\author{
Mare ISAKAR
}

Artiklis on täiendatud Curt Teicherti 1928. aastal esmamainitud liigi Cyclonema (C.) hiiumaa kirjeldust. Uute leidude põhjal on antud ülevaade liigi levikust ja elutingimustest.

\section{ОПИСАНИЕ ГАСТРОПОДЫ СУСLONEMA (CYCLONEMA) HIUUAA TEICHЕRT, 1928 ИЗ ЛЛАНДОВЕРИ (СИЛУРА) ЭСТОНИИ}

\author{
Mape ИСAKAP
}

В статье уточняется описание вида Cyclonema (C.) hiiumaa, установленного Куртом Тейхертом в 1928 г. Рассматривается распространение и образ жизни этого вида на основе новых находок на о-ве Хийумаа. 